\begin{tabular}{|l|l|l||}
\hline \multicolumn{2}{|c|}{ PublisherInfo } \\
\hline \hline PublisherName & $:$ & BioMed Central \\
\hline \hline PublisherLocation & $:$ & London \\
\hline \hline PublisherImprintName & $:$ & BioMed Central \\
\hline \hline
\end{tabular}

\title{
Vaccinia tricks Toll
}

\begin{tabular}{|l|l|l||}
\hline \multicolumn{2}{|c|}{ ArticleInfo } \\
\hline \hline ArticleID & $:$ & 3668 \\
\hline \hline ArticleDOI & $:$ & $10.1186 /$ gb-2000-1-6-reports0079 \\
\hline \hline ArticleCitationID & $:$ & reports0079 \\
\hline \hline ArticleSequenceNumber & $:$ & 18 \\
\hline \hline ArticleCategory & $:$ & Paper report \\
\hline ArticleFirstPage & $:$ & 1 \\
\hline \hline ArticleLastPage & $:$ & 4 \\
\hline \hline & & RegistrationDate : 2000-11-1 \\
ArticleHistory & $:$ & Received \\
& & OnlineDate \\
\hline \hline ArticleCopyright & $:$ & BioMed Central Ltd2000-11-1 \\
\hline \hline ArticleGrants & $:$ & \\
\hline \hline \hline ArticleContext & $:$ & 130591166-4 \\
\hline \hline
\end{tabular}




\section{Rachel Allan}

\section{Abstract}

The first evidence that viruses may subvert signaling pathways from Toll-like receptors within their mammalian hosts has been found.

\section{Significance and context}

The Toll-like receptor/IL-1 receptor (TLR) family of proteins, characterized by an intracellular Toll/ IL-1 receptor (TIR) domain, has recently attracted a great deal of interest. Members of the human TLR family include receptors for the IL-1 and IL-18 cytokines and several newly discovered TLRs whose functional relevance remains largely undetermined. In an innate immune reaction, TLR engagement will trigger the activation of appropriate response genes. The signal is transduced through a series of intermediates including MyD88, which interacts with the activated receptor via its own TIR domain. MyD88 then recruits IRAK (interleukin-1 receptor accessory protein kinase) through a death-domain interaction, thus activating the adaptor protein TRAF6 and ultimately the transcription factor NFKB (see Figure 1). As a result of host-pathogen coevolution, physiologically important immune response pathways are often susceptible to specialized viral countermeasures. For example, human cytomegalovirus expresses several proteins that subvert the host's antigen-presentation system. Similarly, poxviruses encode a variety of decoy receptors that can inhibit the action of response factors including IL-1 and IFN- $\gamma$. Bowie et al. have identified and characterized two vaccinia virus proteins that can subvert multiple Toll pathways in the host. This provides the first evidence of viral evasion of human Toll pathways and emphasizes the immunological importance of Toll systems in our innate immune response. 
Figure 1 Recognition of an appropriate ligand (for example, lipopolysaccharide) triggers the Toll-like receptor to recruit MyD88. MyD88 interacts with the Toll-like receptor through its own Toll/IL-1 receptor domain and in turn engages the serine-threonine kinase IRAK though a death domain. Signal transduction factors such as TRAF6 carry the signal through a series of phosphorylations until NFKB is ultimately released to the nucleus where it can activate the transcription of appropriate immune response genes.

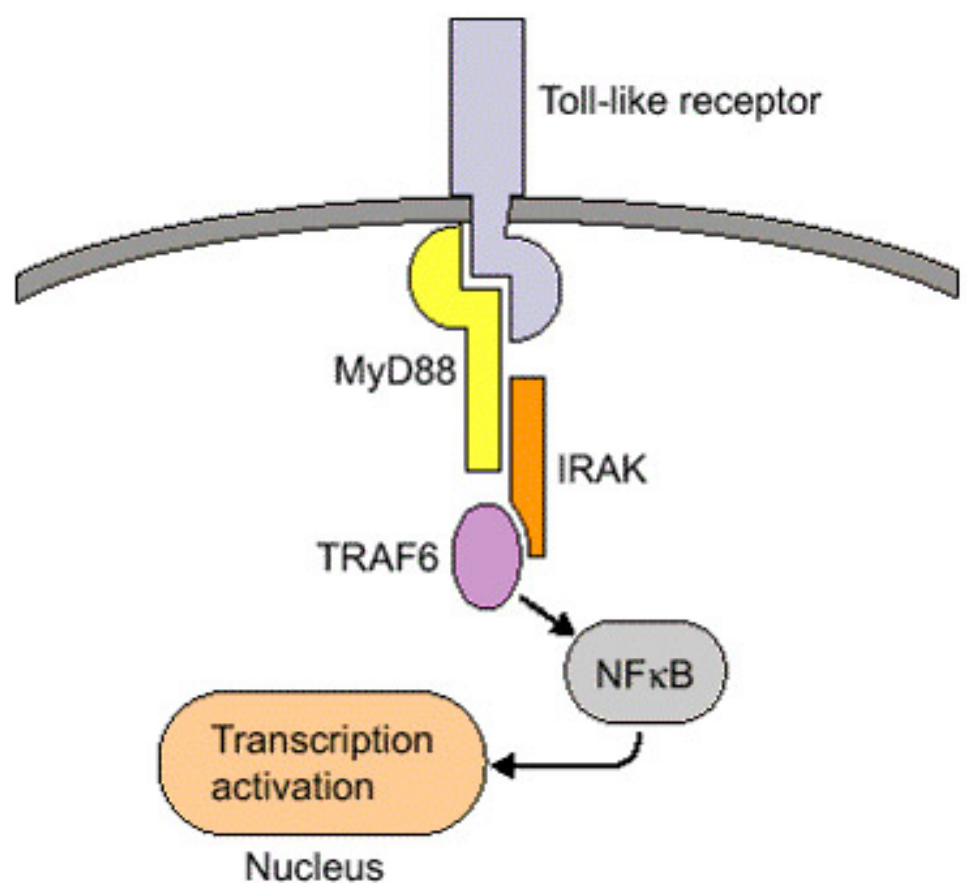

\section{Key results}

A search of the vaccinia virus sequences identified two potential TLR homologs, A46R and A52R. Subsequent cloning confirmed that these proteins each contained a putative TIR domain, although they lacked a further conserved set of amino acids known to be important for TLR signaling. The viral homologs could therefore inhibit Toll signaling by competing for a TIR-dependent substrate while failing to recruit downstream components. To explore this possibility, the authors used a reporter gene system to study the effects of A46R and A52R on the Toll-like IL-1 receptor pathway. Expression of A46R and A52R in human cells was found to inhibit NFאB activation following IL-1 stimulation but had no effect on an unrelated pathway. Inhibition was more profound for the A52R protein. A52R was subsequently coexpressed with high levels of various IL-1 signaling intermediates in an attempt to pinpoint its action within the signaling pathway. Upstream components, including MyD88, failed to compensate for the action of A52R, whereas overexpression of downstream IRAK restored NFKB activation. These results indicate that A52R acts at the level of MyD88, consistent with its predicted TIR-dependent mechanism. Similar experiments performed on the IL-8 and TLR-4 systems confirmed that A52R could inhibit multiple TIR-dependent pathways. 


\section{Conclusions}

The authors conclude that A46R and A52R can effectively inhibit TIR-dependent signaling pathways. These proteins may therefore be useful for defining the importance of TIR-dependent pathways in the host immune response.

\section{Reporter's comments}

The ancient origin of Toll pathways is reflected by their occurrence throughout multicellular organisms - from plants to insects and mammals. Studies of Drosophila Toll proteins have provided valuable insights into the role of these innate pattern-recognition receptors. Thus, we now know that binding of Toll receptors by microbial products such as lipopolysaccharide leads to the activation of appropriate immune defense mechanisms in the host. Cloning by homology has identified several closely related human Toll counterparts whose physiological relevance is now being addressed. For example, recent studies have implicated TLR-2 and TLR-4 in our antibacterial and inflammatory responses. The study of immune evasion mechanisms can provide further insights into the functional importance of immune regulatory molecules in addition to clarifying their physiological roles. If Tolllike pathways are also susceptible to viral subversion, as shown in this paper, then they are likely to be important in a wide range of infections. A common signaling pathway used by multiple innate response proteins would be a particularly suitable target for viral interference.

\section{Table of links}

Proceedings of the National Academy of Sciences of the United States of America

\section{References}

1. Bowie A, Kiss-Toth E, Symons JA, Smith GL, Dower SK, O'Neill LAJ: A46R and A52R from vaccinia virus are antagonists of host IL-1 and toll-like receptor signaling. Proc Natl Acad Sci U S A. 2000, 97: 10162-10167. 0027-8424

This PDF file was created after publication. 